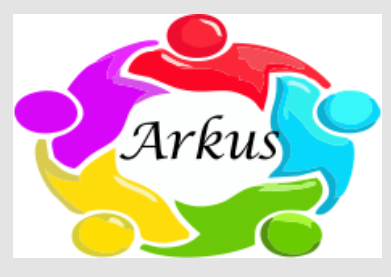

ARKUS

Journal Homepage:

https://hmpublisher.com/index.php/arkus

\title{
Community Attitudes Towards Preserving Nandong Art in Gampong Sambay, Teluk Dalam District, Simuelue Regency
}

\section{Andi Fadinul1*}

${ }^{1}$ Sociology Study Program, Faculty of Social and Political Science, Universitas Teuku Umar, Meulaboh, Indonesia

\section{A R T I C L E I N F O \\ Keywords: \\ Cultural \\ Nandong music \\ Traditional poet \\ Violin \\ Corresponding author: \\ Andi Fadinul \\ E-mail address: \\ andi fadinul@gmail.com}

The author has reviewed and approved the final version of the manuscript.

\begin{abstract}
A B S T R A C T
Nandong is one of the cultures in Simeulue Regency, where this culture is in the form of rhymes or poems accompanied by drums and violins and played by men. Nandong culture or art is usually held on certain occasions, such as weddings and circumcision, but it is also displayed when no certain events occur. In a wedding or circumcision, usually, the host or the person who organizes the event deliberately invites groups or people proficient in performing Nandong to be held at the venue. However, the preservation of Nandong culture seems to be fading due to the development of modern musical instruments so that local culture is rarely displayed. This study aims to explore the attitudes and behavior of the people in Gampong Sambay towards Nandong arts.
\end{abstract}

https://doi.org/10.37275/arkus.v6i1.78

\section{Introduction}

The alteration in people's needs for modern products is natural, and the community's social life dynamics continue to grow. For sociology, society should not be conceived of as a fixed state, but as a process, not as a rigid pseudo-object but as a continuous stream of events. It is recognized that society (group, community, organization, nation, state) can only be said to exist as long as something happens in it, specific actions are taken, certain changes are made, and specific processes are always working. Sociologically it can be said that society is not in a constant state. All social realities are constantly changing with different degrees of speed, intensity, rhythm, and tempo. It is no coincidence that people talk about social life. Since life is motion and change, there is no life, but a completely different state called nothingness or death when it ceases. ${ }^{1-3}$

However, in terms of cultural preservation, the continuous changes in society currently significantly impact people's attitudes in preserving culture. At this time if we see people are more interested in foreign cultures and leave their own culture. The local community's lifestyle, norms and values, customs, and habits are damaged due to the penetration of modern western culture.

In society, culture has an essential function for 
humans and society. The various forces that society and its members face, such as nature and other forces within society itself, are not always suitable for him. In addition, humans and society also need satisfaction, both in the spiritual and material fields. The needs of the people mentioned above are, for the most part, fulfilled by the culture that originates in the community itself. It is mainly said that because human abilities are limited, the ability of culture resulting from his creation is also limited in meeting all needs.

\section{Literature Review}

The formation and change of a person's or society's attitude do not happen by itself. This change can occur due to its relationship with an object, person, group, institution, value through relationships between individuals, groups, communication in newspapers, books, posters, radio, and television. The environment closest to daily life has many roles. So is the case with an object, such as traditional culture or art, as a result of the many alternatives that can affect a person's attitude or society so that interest in the object can change.4-8

At first, Nandong were familiar songs sung by the people of the desert who came to trade to the island of Simeulue, sung in rhymes and depicting stories about human life. However, over time, the poems conveyed were intelligent people; the poems were compiled became an art called Nandong. The poetry conveyed in Nandong tells of human life; the art is often displayed at weddings and feast events to be entertained and give advice to people who are married or feast of the apostle through poems delivered by Nandong. However, this brief history of Nandong is not written because the local government and the people of Simeulue have never conducted research on the history of Nandong and made writing or book, only this brief history is known based on the knowledge of people who understand and enjoy Nandong culture. ${ }^{9-12}$
The meaning of the poetry conveyed in the Nandong art event is advice that tells the dynamics of human life, such as Nandong's poem entitled "Untung (Lucky)" below:

Lain bana rumpun pandan $k u$ (my pandanus clump is very different)

Tidokkan samo jo ilalang (will not be the same as weeds)

Lain bana nasib badan $k u$ (my fate is very different)

Tidokkan samo di untung urang (will not be the same as people's sustenance)

Api sapuntung patawikkan (small fire put together)

Panggang gulamo balik-balik (grilled fish back and forth)

Untung nan jangan di paturuikan (sustenance is not forced)

Asal parangai baik-baik (the important thing is to do good)

This Untung poem tells about sustenance. It means that we should not force ourselves to get a lot of profit/sustenance in a short time because we see other people who are richer than us. However, we must be patient and always kind to others so that other people are also good to us, meaning that when other people are good to us, we get young sustenance. There are many other Nandong poems, and almost all of Nandong's poems are related to the story of human life. 13

However, the preservation of Nandong culture seems to be fading due to the development of modern musical instruments so that local culture is rarely displayed. This is because people prefer music or modern art to enliven the events that are being carried out as mentioned above, on the other hand, there are very few people who understand and are proficient in the knowledge of Nandong art, plus the awareness of people's attitudes in preserving local culture is low. This form can harm Gampong Sambay 
in terms of the loss of regional cultural values that have been inherited from generation to generation by their ancestors. Based on the background of the problems described above, the researchers are interested in studying more deeply how the attitude of Gampong Sambay, Teluk Dalam District, Simeulue Regency in preserving Nandong culture.

\section{Methods}

The research method used is descriptive qualitative because this research was conducted by collecting, processing, presenting, and describing the research results and social phenomena. The source of data in this study is data obtained from observations and interviews with several selected resource persons in the study. The selection of several critical informants in order to obtain more indepth and accurate information about the issues to be discussed, while informants who are part of the population are selected through snowball sampling. The informants in this research are as follows: 2 Geuchik (Nandong artists), and six people from the general public of Gampong Sambay. Data analysis used a qualitative descriptive method, where the discussion of the research and the results were described in words based on the empirical data obtained. The data obtained in this study is qualitative, so the data analysis used is nonstatistical. ${ }^{14}$

\section{Results and discussion}

\section{Gampong Sambay description}

Gampong Sambay is located in Teluk Dalam District, Simeulue Regency, Aceh Province. At first Gampong Sambay was part of Gampong Luan Balu and district of Central Simeulue, but in 2004, District of Central Simeulue was divided into two subdistricts namely; Simeulue Tengah District and Teluk Dalam District and then Luan Balu Gampong which is part of Teluk Dalam District was divided into five gampongs namely; Kuala Baru Village, Bulu Hadik
Village, Luan Balu Village, and Tanjung Raya Village and Sambay Village. Gampong Sambay has three groups of wirit yasin, two groups of taqlim assemblies and three groups of Nandong.

In Nandong art, the tools needed to play Nandong include a drum by hitting it according to the rhythm needed to play Nandong. Likewise, the violin is played by swiping; the violin is also played according to the rhythm desired by Nandong players. The Nandong art is done together by reciting poetry like a rhyme with recitation. Nandong art generally tells about experiences, history, and ways to overcome problems that may arise. ${ }^{15-17}$

\section{The attitude of the Gampong Sambay community in preserving Nandong culture}

In strengthening the orientation of a change process, several factors give strength to the movement of change, which includes attitudes, both on an individual scale and on a group scale, which can appreciate the work of other parties, regardless of the large or small scale of work productivity itself, the ability to tolerate several deviations from the forms or elements of the routine. Indeed, one of the essential characteristics of a creature called a human is as a creature called homo deviant, a creature who likes to deviate from the elements of routine strengthens a habit or mental attitude that can give rewards to other parties (individuals, groups) who excel in innovation, both in the social, economic, and technological fields.

The process of social change does not have to be oriented to the issue of progress or progress alone because it is not impossible that the process of social change leads to the issue of setbacks or towards something or may lead to several aspects or values of life in the society concerned. Humans who live in society must be surrounded by culture, the culture that was inherited by the previous people and carried out by the next generation. Where culture must be maintained so that it is not lost by time which 
continues to challenge humans with new cultures, if humans do not really maintain the culture that their predecessors have inherited, it will disappear from life itself. The disappearance or absence of the culture that the ancestors have inherited to their successors is largely determined by human attitudes; this attitude will take on the role of whether humans will continue to maintain the culture or vice versa, disappear because new cultures emerge that continue to emerge with the development of the times. 18

The attitude of not caring and lack of community participation in preserving our own culture is detrimental to ourselves. Considering the work created by previous people is an identity of a place where culture or art was born. The attitude to preserve this culture must exist in every generation that lives after it. If it is not maintained, such as Nandong art in Gampong Sambay, it will be lost and negatively impact the continuity of cultural identity.

The attitude of the Gampong Sambay community in preserving Nandong culture is far from caring about Nandong culture. The presence of modern music makes people prefer watching modern music rather than watching Nandong. This culture was born by its predecessors, which is full of meaning in the delivery of each appearance. With this indifferent attitude, Nandong will gradually be forgotten; now, it is complicated to find Nandong art in a place where a feast is held if someone asks for it from the party who is doing the party or vice versa if someone offers Nandong to the party doing the feast. As stated by Rizaldi (Geuchik Gampong Sambay). The people in Gampong Sambay have very little participation in preserving Nandong culture. People prefer the keyboard rather than Nandong. Both young and old are watching keyboards more than watching Nandong. If there is Nandong, it is only done during practice, it is only occasionally, and it is rarely done in a public place to be shown while preserving one's own culture. ${ }^{19}$
Along with the times, many new cultures enter without being dammed amid rural communities. The arrival of a new culture is one of the challenges for the community; here, the community's attitude will determine whether or not the community owns the culture will survive. The culture that the ancestors have inherited may disappear by itself because of the people's attitude who do not want to know about their own culture.

An increase in the number of people in rural areas who participate or are directly involved in regional culture or art performance can be a benchmark that the public's concern for preserving culture is excellent. Vice versa, if the more extended the number of people directly involved in the performance of a regional culture or art decreases, it can be said that the community is less concerned about preserving regional culture.

Attitudes or actual actions of individuals and communities towards cultural preservation should be improved so that the culture owned by the community itself is not lost. In addition to maintaining culture, which is the result of human creation, culture is one media to improve interaction patterns and build social relations between communities.

Often we hear and see the culture of an area that has been inherited from generation to generation. Indeed the original culture of the area is claimed by other regions as their culture. This could be because people's attitudes in maintaining and preserving their own culture are so low that it is easy for other people to take over that culture-likewise, the Nandong culture, which the Simeulue people own at this time.

Suppose people's awareness is getting lower towards the preservation of Nandong culture. In that case, this culture may at some point be lost and even claimed by other regions as their culture, even though if we look at Nandong culture, it has enormous religious values because the spoken poetry is advice and praise. And so on to people who want to 
start a new life and families who hold the event. The genuine attitude of the community in maintaining cultural values that have been inherited from generation to generation by their ancestors is a form of appreciation for the people who have created the culture itself. This is following what one expert said. Attitude is something that determines the nature, nature, both current and future actions. Therefore the psychologist W.J. Thomas in Abu Ahmadi defines "attitude as an individual consciousness that determines actions that are real or that may occur in social activities. In this case, Thomas states that a person's attitude is always directed towards a particular thing or object. $20-21$

In preserving the Nandong culture, the people of Gampong Sambay should be aware of their attitude to decide what to do in preserving the Nandong art culture, which is now lost during the Gampong Sambay community. Preservation of things such as local culture or arts should indeed be the obligation of every individual and community who is the owner of that culture because the culture or art that exists in that society can be said to be the community's identity. In the concept of group, Farancis in Kamanto said that if a racial group is based on physical characteristics, then an ethnic or tribal group is based on cultural similarities. The spirit and understanding of the community towards the sustainability of Nandong needs to be created. Because the identity of a region or a nation cannot be separated from the existing culture, a culture that does not conflict with the norms that apply in people's lives, a culture that the community can accept without losing the religious principles that exist in the life of the Gampong Sambay community.

\section{Conclusion}

The attitude of the Gampong Sambay community towards the preservation of Nandong culture is fragile; the participation of the Sambay village community is meager in preserving Nandong culture; this is because Nandong art has never been shown in the Sambay village community so that people forget about Nandong art. And the low demand for Nandong art to the community during the celebration event at the Gampong Sambay Community.

\section{References}

1. Akhwat, Perubahan Sosial Dan Budaya, PT. Express, Jakarta. 2010.

2. Ahmadi, Abu. Psikologi Sosial. Edisi Revisi. Rineka Cipta. Jakarta. 2007.

3. Arikunto, Suhsarsimi. Prosedur Penelitian. Rineka Cipta. Jakarta. 2006.

4. Abdul Syani, Keberagaman Budaya Indonesia, Media Press, Jakarta. 1995.

5. Burhan Mugin, Penelitian Kualitatif : Ekonomi, Komunikasi, Kebujakan Publik dan Ilmu Sosial Lainnya. Kencana Prenada Media Group. Jakarta. 2008.

6. Emha Ainun Nadjib. Terus Mencoba Budaya Tanding. Pustaka Pelajar. Yogyakarta. Indonesia. 1987.

7. Emzir, Metodologi Penelitian Kualitatif Analisis Data. PT Raja Garafindo Persada. Jakatra. 2010.

8. Faisal, Sanapiah. Format-format Penelitian Sosial, Dasar-Dasar dan Aplikasi. PT Raja Garafindo Persada. Jakatra. 2005.

9. Giddens, Anthony \& Jonatan Turner. Social The Theory Today, Panduan Sistematis Tradisi dan Tren Terdepan Teori Sosial. Pustaka Pelajar Yogyakarta. 2008.

10. Jacobus Ranjabar, Sosiologi, Reneka Cipta, Jakartra. 2008

11. Koentjaraningrat. Pengantar Ilmu Antropologi. Rineka Cipta Jakarta

12. Miriam Budiardjo. 2008. Dasar-Dasar Ilmu Politik. PT. Garamedia Pustaka Utama. Jakarta. 2006.

13. Malihah, Masyarakat Dalam Kebudayaan, Graha Cipta, Jakarta. 2003. 
14. Rush, Michael \& Phillip Althoff. Pengantar Sosiologi Politik. PT Raja Garafindo Persada. Jakatra. 2007.

15. Sugiyono, Metode Penelitian Kuantitatif, Kualitatif dan $\mathrm{R}$ \& D, Bandung: Alfabeta. 2011.

16. Sunaryadi, Tantangan Dan Perubahan, Arita Press, Bandung. 2000.

17. Sunarto, Kamanto. Pengantar Sosiologi. Edisi Revisi. Fakultas Ekonomi Universitas Indonesia. Jakarta. 2004.
18. Soekanto, Soerjono. Sosiologi Suatu Pengantar. PT Raja Grafindo Persada. Jakarta. 2006.

19. Sztompka, Piort. Sosiologi Perubahan Sosial. Prenada Media. Jakarta. Wiryohandoyo, Sudarno. Perubahan Sosial, Sketsa Teori dan Refleksi. 2005.

20. Metodologi Kasus Indonesia. PT Tiara Wacana. Yogyakarta.

21. Yopy Andri, Nandong Seni Tradisional Simeulue Yang Terlupakan, Graha Cipta. Yogyakarta. 2009 